\title{
Effects of the Amount of Chopped Hay or Cottonseed Hulls in a Textured Calf Starter on Young Calf Performance
}

\author{
T. M. Hill, ${ }^{1}$ H. G. Bateman II, J. M. Aldrich, and R. L. Schlotterbeck \\ Akey Nutrition and Research Center, PO Box 5002, Lewisburg, OH 45338
}

\section{ABSTRACT}

Four trials were conducted to compare the concentrations of cottonseed hulls (CSH) and chopped hay in textured starters on calf body weight gain, intake, and efficiency. Holstein bull calves (initially 3 and $4 \mathrm{~d}$ old in studies 1,2 , and 3 , and 59 to $60 \mathrm{~d}$ old in study 4 ) were fed ad libitum starters (geometric mean particle size of approximately $2,00022 \mathrm{mim}$; equal at $18 \%$ crude protein as-fed; digestible energy concentration declined with increasing roughage). All calves were weaned at 31 to $32 \mathrm{~d}$ of age. Calves were housed in individual pens bedded with straw within an unheated, curtain-sided nursery for d 0 to 56 and then grouped in pens of 6 calves for $\mathrm{d} 56$ to 84 . Study 1 compared textured starters containing A) $0 \%$ or B) $5 \% \mathrm{CSH}$ for the first $56 \mathrm{~d}$. On d 56 (through d 84), calves fed diet A were switched to diet $\mathrm{C}$, which contained $0 \% \mathrm{CSH}$ and $5 \%$ chopped hay; calves fed diet $\mathrm{B}$ were switched to diet $\mathrm{D}$, which contained 5\% CSH and 5\% hay. Study 2 compared textured starters fed from 0 to $84 \mathrm{~d}$ that contained A) $0 \% \mathrm{CSH}$ and $0 \%$ chopped hay, B) $5 \% \mathrm{CSH}, \mathrm{C}) 10 \% \mathrm{CSH}$, or D) $5 \%$ chopped hay. Study 3 compared textured starters fed from 0 to $56 \mathrm{~d}$ that contained A) $0 \%$, B) $2.5 \%$, and C) $5 \%$ chopped hay. Study 4 compared textured starters fed from d 56 to 84 that contained A) $5 \%$ and B) $15 \%$ chopped hay. In study 1, calves fed the diet with $5 \%$ CSH consumed less starter and were less efficient from 28 to $56 \mathrm{~d}$ than calves fed $0 \% \mathrm{CSH}$. Calves fed the diet with $0 \% \mathrm{CSH}$ tended to have a greater average daily gain (ADG) and empty body weight ADG (EBWADG) from 28 to $84 \mathrm{~d}$ than calves fed the starter with $5 \%$ $\mathrm{CSH}$. In study 2, EBWADG declined linearly from 0 to $28 \mathrm{~d}$, and both ADG and EBWADG decreased from 28 to $56 \mathrm{~d}$ as $\mathrm{CSH}$ percentage increased in the starter. Both ADG and EBWADG responded quadratically to $\mathrm{CSH}$ percentage in the starter from 56 to $84 \mathrm{~d}$, with calves fed the starter containing $10 \% \mathrm{CSH}$ having the slowest ADG and EBWADG. Calves between 56 and 84

Received December 10, 2007.

Accepted March 5, 2008.

${ }^{1}$ Corresponding author: mhill@akey.com d that were fed starters with 5\% roughage appeared more efficient than calves fed starters with 0 or $10 \%$ roughage. In study 3, ADG, EBWADG, starter intake, and efficiency declined linearly as hay percentage increased in the starter from 28 to $56 \mathrm{~d}$. In study 4, ADG, EBWADG, and starter intake were less for calves fed starters with 15 vs. 5\% hay. In conclusion, adding lowenergy fibrous feeds to starters with adequate coarseness (approximately 2,000 $\mu \mathrm{m}$ ) reduced ADG in weaned calves less than 3 mo old bedded on straw.

Key words: calf, fiber, roughage, starter

\section{INTRODUCTION}

Consumption of concentrates and forages by calves stimulates the microbial population of the rumen and their end products that initiate rumen epithelial development. Concentrates are more effective at this than forages (Hibbs et al., 1956; Warner et al., 1956). Rumen papillae development is stimulated more by butyrate, followed by propionate, and the least by acetate (Flatt et al., 1958; Sander et al., 1959; Tamate et al., 1962), again suggesting that concentrates are more beneficial than forages. However, rumen parakeratosis can result in reduced absorption by the epithelium of microbial end products (Brownlee, 1956) if feed particle size is too small and the abrasiveness of the diet is too low (McGavin and Morrill, 1976). Additionally, if the dietary particle size is too small, rumen muscular development, volume enlargement, and overall rumen development will be slowed (Brownlee, 1956; Hibbs et al., 1956). Porter et al. (2007) defined the minimal particle size of a starter diet (fed in stalls with no bedding) to be approximately $2,000 \mu \mathrm{m}$ to initiate rumination and microbial end-product production and to enhance calf ADG. Warner et al. (1956) and Stobo et al. (1966) reported that as forage percentage increased in the diet of the young calf, empty BW ADG (EBWADG) decreased. Jahn et al. (1970) fed older calves (between 8 and 20 wk of age) diets with 0 to $60 \%$ roughage and observed EBWADG to decrease as roughage increased.

Many US producers appear to be ignoring this wealth of research based on a USDA survey (Heinrichs et al., 1994). This survey showed that $67 \%$ of producers fed 
calves some roughage by 4 wk of age, $12 \%$ of producers did not feed forage before calves were 8 wk of age, and the average weaning age was $7.9 \mathrm{wk}$. Kincaid (1980) and Coverdale et al. (2004) have reported that feeding hay improved $\mathrm{ADG}$ in calves less than $12 \mathrm{wk}$ of age, supporting the practices of many US producers in the survey. Kincaid (1980) fed a 13 to $14.6 \%$ CP pelleted starter with 0 to $20 \%$ alfalfa as pellets or long hay and reported increases in ADG up to $32 \%$ from feeding alfalfa, whereas Coverdale et al. (2004) fed a $20 \% \mathrm{CP}$ textured starter with $0,7.5$, and $15 \%$ chopped hay and reported 12 to $34 \%$ increases in ADG vs. 0\% hay.

Because of these contradicting data sets, the objective of this series of 4 studies was to test low inclusions of roughage ( 0 to $15 \%)$ in starters for calves between $3 \mathrm{~d}$ and $12 \mathrm{wk}$ of age to measure ADG, EBWADG, intake, efficiency, and other parameters.

\section{MATERIALS AND METHODS}

A total of 192 single-source male Holstein calves were used for a series of 4 studies with 48 calves assigned to each. In studies 1,2 , and 3 , bull calves were initially (d 0) 3 to $5 \mathrm{~d}$ old and $42 \pm 1 \mathrm{~kg}$ BW. Study 4 used steer calves that had previously been used in an unrelated trial. Calves used in study 4 were initially (d 0) 58 to $60 \mathrm{~d}$ old and weighed $70 \pm 0.5 \mathrm{~kg}$. Studies 1 and 2 were $84 \mathrm{~d}$ long, study 3 was $56 \mathrm{~d}$ long, and study 4 was 28 d. Calves in studies 1, 2, and 3 were received at midday after a 3-h transit. Calves were fed milk replacer (MR) at the p.m. feeding. The day after arrival at approximately $1200 \mathrm{~h}$ the calves were weighed, blood was sampled from the jugular vein $(10-\mathrm{mL}$ glass Vacutainer, Becton Dickinson, Franklin Lakes, NJ), and serum protein was measured using a refractometer (Atago US Inc., Bellevue, WA). Calves were randomly assigned to treatment. Calves were weighed on d 0, 28, and 56 at approximately $1200 \mathrm{~h}$. In study 4, calves were blocked by previous experimental treatment before being randomly assigned to treatments. Those calves had been weaned at $28 \mathrm{~d}$ from a $26 \%$ milk CP, $17 \%$ fat MR (Pinnacle, Akey, Lewisburg, OH) at $0.681 \mathrm{~kg} / \mathrm{d}(0.15 \mathrm{~kg} / \mathrm{L})$. A textured starter with the same composition as starter A in study 3 had been fed to these calves for $56 \mathrm{~d}$ before study 4. Body weights were taken at approximately $1200 \mathrm{~h}$ on $\mathrm{d} 0$ and 28 . All calves were housed in individual 1.2- $\times 2.4-\mathrm{m}$ pens in a curtain sidewall barn with no added heat until 58 to $60 \mathrm{~d}$ old, at which time calves were moved to group pens of 6 calves per pen. Group pens consisted of $5.5 \mathrm{~m}^{2}$ of outside pen space and 0.9 $\mathrm{m}^{2}$ of inside pen space per calf. The individual pens and inside pen space in the group pens were bedded with straw.
Dry feed offered and refused were weighed daily. Fecal scores were assigned daily based on a 1 to 5 scale ( 1 being normal, thick in consistency; 2 being normal, but less thick; 3 being abnormally thin but not watery; 4 being watery; 5 being watery with abnormal coloring). Hip widths were measured with a caliper initially and every 2 wk thereafter. Calf EBWADG was estimated by first estimating gut fill (fill as a percentage of $\mathrm{BW}=$ $10.4-0.39 \operatorname{diet} \mathrm{CP} \%+0.41 \operatorname{diet} \mathrm{ADF} \%$ ) and correcting BW as described by Jahn et al. (1976).

Calves were cared for by acceptable practices as described in the Guide for the Care and Use of Agricultural Animals in Agricultural Research and Teaching (FASS, 1999). Vaccines and health protocols were based on the recommendations of a veterinarian. Calves received an intranasal tissue-sensitive respiratory disease vaccine (TSV-2, Pfizer, Exton, PA) and subcutaneous injections of vitamins A, D, E (Vital E-A + D, Schering-Plough Animal Health, Union, NJ), and Se (MU-SE, Schering-Plough Animal Health) upon arrival. Calves received an intramuscular respiratory disease vaccine (Bovashield Gold 5, Pfizer) at d 7 and again at d 28. At $\mathrm{d} 14$ they received an intramuscular vaccine for types $\mathrm{C}$ and D clostridium (Ultra Choice 7, Pfizer). A pasteurella vaccine (Presponse HM, Fort Dodge, Fort Dodge, IA) was administered intramuscularly on d 28 and 42 . Calves were castrated and dehorned on d 36. Digestive infections were diagnosed based on rectal temperatures $\left(>39.5^{\circ} \mathrm{C}\right)$, lack of vitality, and fecal scores $>2$. Animals that required medication for digestive infections were treated per veterinary recommendation with subcutaneous ceftiofur sodium (Naxcel, Pharmacia and Upjohn, Kalamazoo, MI) and treatments were recorded daily. All medical treatments for digestive upsets (scouring) were minor and occurred before $31 \mathrm{~d}$ of age.

Study 1 compared textured starters (Table 1) containing A) $0 \%$ or B) $5 \%$ cottonseed hulls (CSH) for the first $56 \mathrm{~d}$ using 48 calves randomly assigned to each treatment (24/treatment). On d 56, calves fed diet A were switched to diet $\mathrm{C}$, which contained $0 \% \mathrm{CSH}$ and $5 \%$ hay; calves fed diet $\mathrm{B}$ were switched to diet $\mathrm{D}$, which contained 5\% CSH and 5\% hay. These diets (Table 1) were fed through the end of the trial on $\mathrm{d} 84$. All calves were fed a $20 \%$ milk CP, $20 \%$ fat MR (White Gold, Akey) at $0.454 \mathrm{~kg} / \mathrm{d}(0.12 \mathrm{~kg} / \mathrm{L})$ halved into a.m and p.m. feedings for $25 \mathrm{~d}$, followed by $0.227 \mathrm{~kg} / \mathrm{d}$ for $\mathrm{d} 26$ to 28 (a.m. feeding only). Calves were maintained in individual pens for d 0 to 56 and then grouped into pens of 6 calves on d 56 to 84. Starters and water were fed ad libitum. Study 1 was conducted March through June. The average temperature was $14^{\circ} \mathrm{C}$ and ranged from -7 to $31^{\circ} \mathrm{C}$ based on hourly measurements.

Study 2 compared textured starters containing A) 0\% $\mathrm{CSH}$ and $0 \%$ hay, B) $5 \% \mathrm{CSH}, \mathrm{C}) 10 \% \mathrm{CSH}$, and D) $5 \%$ 


\begin{tabular}{|c|c|c|c|c|c|c|c|c|c|c|c|c|c|}
\hline \multirow[b]{2}{*}{ Item } & \multicolumn{4}{|c|}{ Study 1} & \multicolumn{4}{|c|}{ Study 2} & \multicolumn{3}{|c|}{ Study 3} & \multicolumn{2}{|c|}{ Study 4} \\
\hline & $\begin{array}{l}\text { A: } 0 \% \\
\text { CSH }\end{array}$ & $\begin{array}{l}\text { B: } 5 \% \\
\text { CSH }\end{array}$ & $\begin{array}{l}\text { C: } 0 \% \\
\text { CSH }\end{array}$ & $\begin{array}{l}\text { D: } 5 \% \\
\text { CSH }\end{array}$ & $\begin{array}{l}\text { A: } 0 \% \\
\text { CSH }\end{array}$ & $\begin{array}{l}\text { B: } 5 \% \\
\text { CSH }\end{array}$ & $\begin{array}{l}\text { C: } 10 \% \\
\text { CSH }\end{array}$ & $\begin{array}{l}\text { D: } 5 \% \\
\text { Hay }\end{array}$ & $\begin{array}{l}\text { A: } 0 \% \\
\text { Hay }\end{array}$ & $\begin{array}{c}\text { B: } 2.5 \% \\
\text { Hay }\end{array}$ & $\begin{array}{l}\text { C: } 5 \% \\
\text { Hay }\end{array}$ & $\begin{array}{l}\text { A: } 5 \% \\
\text { Hay }\end{array}$ & $\begin{array}{l}\text { B: } 10 \% \\
\text { Hay }\end{array}$ \\
\hline \multicolumn{14}{|l|}{ Ingredient, $\%$ as-fed } \\
\hline Hay & 0.00 & 0.00 & 5.00 & 5.00 & 0.00 & 0.00 & 0.00 & 5.00 & 0.00 & 2.50 & 5.00 & 5.00 & 15.00 \\
\hline $\mathrm{CSH}$ & 0.00 & 5.00 & 0.00 & 5.00 & 0.00 & 5.00 & 10.00 & 0.00 & 0.00 & 0.00 & 0.00 & 0.00 & 0.00 \\
\hline Corn & 40.00 & 35.00 & 35.00 & 30.00 & 40.00 & 35.00 & 30.00 & 35.00 & 40.00 & 37.50 & 35.00 & 35.00 & 30.00 \\
\hline Oats & 25.00 & 25.00 & 25.00 & 25.00 & 25.00 & 25.00 & 25.00 & 25.00 & 25.00 & 25.00 & 25.00 & 25.00 & 20.00 \\
\hline Soybean meal ${ }^{1}$ & 22.50 & 23.25 & 21.60 & 24.00 & 22.50 & 23.25 & 24.00 & 21.60 & 21.60 & 21.60 & 21.60 & 21.60 & 18.60 \\
\hline Wheat middlings ${ }^{1}$ & 5.00 & 4.25 & 6.00 & 3.50 & 5.00 & 4.25 & 3.50 & 6.00 & 6.00 & 6.00 & 6.00 & 6.00 & 9.00 \\
\hline Liquid molasses & 3.00 & 3.00 & 3.00 & 3.00 & 3.00 & 3.00 & 3.00 & 3.00 & 3.00 & 3.00 & 3.00 & 3.00 & 3.00 \\
\hline Ca carbonate ${ }^{1}$ & 1.15 & 1.10 & 1.05 & 1.05 & 1.15 & 1.10 & 1.05 & 1.05 & 1.05 & 1.05 & 1.05 & 1.05 & 1.05 \\
\hline Salt $^{1}$ & 0.75 & 0.75 & 0.75 & 0.75 & 0.75 & 0.75 & 0.75 & 0.75 & 0.75 & 0.75 & 0.75 & 0.75 & 0.75 \\
\hline Dicalcium phosphate $^{1}$ & 0.70 & 0.75 & 0.70 & 0.80 & 0.70 & 0.75 & 0.80 & 0.70 & 0.70 & 0.70 & 0.70 & 0.70 & 0.70 \\
\hline Pellet binder ${ }^{1}$ & 0.60 & 0.60 & 0.60 & 0.60 & 0.60 & 0.60 & 0.60 & 0.60 & 0.60 & 0.60 & 0.60 & 0.60 & 0.60 \\
\hline Dry molasses ${ }^{1}$ & 0.60 & 0.60 & 0.60 & 0.60 & 0.60 & 0.60 & 0.60 & 0.60 & 0.60 & 0.60 & 0.60 & 0.60 & 0.60 \\
\hline Premix $^{1}$ & 0.60 & 0.60 & 0.60 & 0.60 & 0.60 & 0.60 & 0.60 & 0.60 & 0.60 & 0.60 & 0.60 & 0.60 & 0.60 \\
\hline Mg oxide ${ }^{1}$ & 0.05 & 0.05 & 0.05 & 0.05 & 0.05 & 0.05 & 0.05 & 0.05 & 0.05 & 0.05 & 0.05 & 0.05 & 0.05 \\
\hline Decoquinate $6 \%^{1}$ & 0.05 & 0.05 & 0.05 & 0.05 & 0.05 & 0.05 & 0.05 & 0.05 & 0.05 & 0.05 & 0.05 & 0.05 & 0.05 \\
\hline \multicolumn{14}{|l|}{ Nutrient, $\%$ as-fed } \\
\hline DM & 87.3 & 87.9 & 88.1 & 87.5 & 87.1 & 87.3 & 87.3 & 87.5 & 87.2 & 87.9 & 87.8 & 88.2 & 88.4 \\
\hline $\mathrm{CP}$ & 18.4 & 18.0 & 18.1 & 18.2 & 18.1 & 17.8 & 17.9 & 18.3 & 17.8 & 18.0 & 18.4 & 18.1 & 18.4 \\
\hline $\mathrm{ADF}$ & 5.6 & 8.1 & 8.5 & 13.2 & 5.8 & 9.3 & 12.9 & 8.7 & 5.8 & 7.0 & 8.6 & 8.5 & 9.8 \\
\hline $\mathrm{NDF}$ & 14.2 & 17.0 & 16.3 & 21.3 & 14.1 & 17.5 & 20.9 & 16.3 & 14.6 & 15.3 & 16.2 & 16.3 & 21.1 \\
\hline Ash & 5.9 & 6.4 & 6.3 & 6.4 & 5.8 & 6.1 & 6.2 & 6.5 & 6.1 & 6.3 & 6.6 & 6.6 & 7.5 \\
\hline $\mathrm{Ca}$ & 0.77 & 0.72 & 0.75 & 0.79 & 0.72 & 0.69 & 0.73 & 0.74 & 0.70 & 0.71 & 0.76 & 0.76 & 0.77 \\
\hline $\mathrm{P}$ & 0.54 & 0.53 & 0.52 & 0.54 & 0.53 & 0.50 & 0.53 & 0.54 & 0.50 & 0.53 & 0.55 & 0.55 & 0.51 \\
\hline Calculated $\mathrm{DE},{ }^{2} \mathrm{Mcal} / \mathrm{kg}$ & 3.1 & 3.1 & 3.1 & 3.0 & 3.1 & 3.1 & 3.0 & 3.1 & 3.1 & 3.1 & 3.1 & 3.1 & 3.0 \\
\hline $\begin{array}{l}\text { Geometric mean } \\
\text { particle size, }{ }^{3} \mu \mathrm{m}\end{array}$ & 2,050 & 1,991 & 2,064 & 2,056 & 2,046 & 1,990 & 1,953 & 2,061 & 2,053 & 2,062 & 2,069 & 2,072 & 2,087 \\
\hline Particles $>1,180 \mu \mathrm{m},{ }^{3} \%$ & 80 & 79 & 80 & 82 & 80 & 79 & 79 & 80 & 80 & 81 & 81 & 81 & 79 \\
\hline
\end{tabular}

${ }^{1}$ These ingredients were pelleted into one supplement. The premix contained trace minerals and vitamins and was labeled (per kilogram) $1.6 \mathrm{mg}$ of $\mathrm{Cu}, 9.4 \mathrm{mg}$ of $\mathrm{Fe}, 5.4$ $\mathrm{mg}$ of Mn, $0.041 \mathrm{mg}$ of Se, $6.7 \mathrm{mg}$ of Zn, 384,091 IU of vitamin A, 127,727 IU of vitamin D, and 3,307 IU of vitamin E as-fed (Akey, Lewisburg, OH); Decoquinate (Alpharma Inc., Fort Lee, NJ).

${ }^{2} \mathrm{DE}=$ digestible energy; NRC, 2001.

${ }^{3}$ Warner (1991) and Porter et al. (2007) suggested that approximately $80 \%$ or more of the particles in a complete starter should be greater than $1,190 \mu \mathrm{m}$ and have a weighted mean particle size of approximately $2,000 \mu \mathrm{m}$ or greater. 
hay for the 84-d study. All calves (48 total; 12/treatment) were fed a $26 \%$ milk CP, $17 \%$ fat MR (Pinnacle, Akey) at $0.681 \mathrm{~kg} / \mathrm{d}(0.15 / \mathrm{L})$ halved into a.m. and p.m. feedings for $25 \mathrm{~d}$, followed by $0.340 \mathrm{~kg} / \mathrm{d}$ for d 26 to 28 (a.m. feeding only). Calves were maintained in individual pens for $\mathrm{d} 0$ to 56 and then grouped into pens of 6 calves ( 2 pens/treatment) on d 56 to 84 . Calves were maintained on the same starter for all $84 \mathrm{~d}$. Starters and water were fed ad libitum. Study 2 was conducted February through May. The average temperature was $5^{\circ} \mathrm{C}$ and ranged from -21 to $29^{\circ} \mathrm{C}$ based on hourly measurements.

Study 3 compared textured starters containing A) $0 \%$, B) $2.5 \%$, and C) $5 \%$ hay for the 56 -d study. All calves ( 48 total; $16 /$ treatment) were fed a $26 \%$ milk CP, $17 \%$ fat MR (Pinnacle, Akey) at $0.681 \mathrm{~kg} / \mathrm{d}(0.15 \mathrm{~kg} / \mathrm{L})$ halved into a.m. and p.m. feedings for $25 \mathrm{~d}$, followed by $0.340 \mathrm{~kg} / \mathrm{d}$ for d 26 to 28 (a.m. feeding only). Calves were maintained in individual pens for $\mathrm{d} 0$ to 56 . Starters and water were fed ad libitum. Study 3 was conducted September through November. The average temperature was $10^{\circ} \mathrm{C}$ and ranged from -6 to $28^{\circ} \mathrm{C}$ based on hourly measurements.

Study 4 compared textured starters containing A) 5\% and B) $15 \%$ hay for the 28-d study. Calves (48) were maintained group pens of 6 calves (4 pens/treatment). Starters and water were fed ad libitum. Study 4 was conducted August through September. The average temperature was $23^{\circ} \mathrm{C}$ and ranged from 10 to $35^{\circ} \mathrm{C}$ based on hourly measurements.

The feeds (Table 1) were tested for DM, CP, fat, ash, $\mathrm{Ca}$, and $\mathrm{P}$ (AOAC, 1996; Table 1), NDF with ash by the procedure of Van Soest et al. (1991) without sodium sulfite or $\alpha$-amylase, and ADF with ash (Robertson and Van Soest, 1981). The hay was mixed, mostly grass (timothy, Phleum pratense L.) and averaged $89.8 \% \mathrm{DM}$, $14.2 \% \mathrm{CP}, 29.5 \% \mathrm{ADF}$, and $46.6 \% \mathrm{NDF}$ (as-fed). The $\mathrm{CSH}$ averaged $90.2 \% \mathrm{DM}, 3.4 \% \mathrm{CP}, 57.3 \% \mathrm{ADF}$, and $79.2 \% \mathrm{NDF}$ (as-fed). Feeds were sieved using wet and dry sieving methods (Shaver et al., 1988) using a vibratory sieve shaker (Fritsch, Oberstein, Germany), and geometric mean particle sizes were determined (ASAE, 1983; Tables 1 and 2).

Data from studies 1, 2, and 3 were analyzed separately as completely randomized designs using the GLM procedure of SAS (version 9.13, SAS Institute Inc., Cary, NC). The model employed for studies 1, 2, and 3 was $Y_{i j}=\mu+T_{i}+\varepsilon_{i j}$, where the dependent variable $\mathrm{Y}_{\mathrm{ij}}$ is the measured response for calf $\mathrm{j}$ in treatment $\mathrm{i} ; \mu$ is the overall population mean; $T_{i}$ is the effect of treatment $i$; and $\varepsilon_{i j}$ the residual error for calf $j$ on treatment i. Study 4 was analyzed as a randomized complete block design using SAS. The model employed was $\mathrm{Y}_{\mathrm{ijk}}=\mu+$ $\mathrm{B}_{\mathrm{i}}+\mathrm{T}_{\mathrm{j}}+\varepsilon_{\mathrm{ijk}}$, where the dependent variable $\mathrm{Y}_{\mathrm{ijk}}$ is the measured response for pen $\mathrm{k}$, in block $\mathrm{i}$, on treatment $j ; \mu$ is the overall population mean; $B_{i}$ the effect of the ith block; $T_{j}$ the effect of treatment $j$; and $\varepsilon_{i j k}$ the residual error for pen $\mathrm{k}$ in block $\mathrm{i}$ on treatment $\mathrm{j}$. In study 2 , linear and quadratic contrasts were used to further characterize the treatment means of 0,5 , and $10 \% \mathrm{CSH}$ diets, and the treatment means of the $5 \% \mathrm{CSH}$ and $5 \%$ hay diets were separated with a contrast statement. In study 3 , the treatment means of $0,2.5$, and $5 \%$ hay diets were further characterized using a linear and quadratic contrast. Data reported are least squares means for the experimental unit of calf for d 0 to 56 in studies 1,2 , and 3. Data reported are least squares means for the experimental unit of pen for d 56 to 84 in studies 1,2 , and 4.

\section{RESULTS}

These 4 studies utilized starters with a geometric mean particle size of approximately 2,000 $\mathrm{m} \mu$, with approximately $80 \%$ of the particles greater than 1,180 $\mathrm{mm}$ (Table 1), similar to the minimal coarseness or particle size suggested by Warner (1991) and Porter et al. (2007). They were also larger (coarser) than the smallest particle size diet fed by Greenwood et al. (1997) that was suggested to be too small in particle size. Adding the small concentrations of CSH or hay to the complete diets in these studies did not greatly affect their particle size. The chopped hay did provide particles that were greater than $8,000 \mathrm{~mm}$ ( $17 \%$ of the particles), whereas none of the other dietary ingredients were that large (Table 2). The hay did have a large amount of particles less than $1,180 \mu \mathrm{m}$ ( $27 \%$ of the particles).

No calves died or were removed from the studies. In each study, there were no differences $(P>0.05)$ in initial BW, serum protein, or hip widths.

In study 1 , calves fed the diet with $5 \% \mathrm{CSH}$ consumed $7 \%$ more starter and more $\mathrm{NDF}$, and were $12 \%$ less efficient from 28 to $56 \mathrm{~d}$ than calves fed $0 \% \mathrm{CSH}(P<$ 0.05; Table 3). Also, calves fed the diet with 5\% CSH had $7 \%$ less change in hip width but consumed more NDF from 56 to $84 \mathrm{~d}$ than calves fed $0 \% \mathrm{CSH}(P<0.05)$. Calves fed the diet with $0 \% \mathrm{CSH}$ tended $(P<0.15)$ to have a 4 to $7 \%$ greater $\mathrm{ADG}$ and EBWADG from 28 to $84 \mathrm{~d}$ than calves fed the starter with $5 \% \mathrm{CSH}$. No other measurements differed between starters $(P>0.15)$.

In study 2, ADG tended $(P<0.15)$ to decrease linearly from 1 to $28 \mathrm{~d}$, EBWADG declined linearly $(P<0.05)$ from 1 to $28 \mathrm{~d}$, and both ADG and EBWADG decreased $(P<0.05)$ from 28 to $56 \mathrm{~d}$ and 1 to $56 \mathrm{~d}$ as CSH percentage increased in the starter (Table 4). Both ADG and EBWADG responded quadratically $(P<0.05)$ to $\mathrm{CSH}$ percentage in the starter from 56 to $84 \mathrm{~d}$, with calves fed the starter containing 10\% CSH having the lowest 
Table 2. Retention of feed particles on various sieves from wet sieving of ingredients and selected contrasting diets

\begin{tabular}{|c|c|c|c|c|c|c|}
\hline & Study 1 & Study 4 & Study 1 & $\begin{array}{l}\text { Study } 1 \\
\text { Diet A }\end{array}$ & $\begin{array}{l}\text { Study } 1 \\
\text { Diet B }\end{array}$ & $\begin{array}{c}\text { Study } 4 \\
\text { Diet B }\end{array}$ \\
\hline $\begin{array}{l}\text { Size of } \\
\text { opening, } \mu \mathrm{m}\end{array}$ & $\begin{array}{l}\text { Cottonseed } \\
\text { hulls (CSH) }\end{array}$ & $\begin{array}{c}\text { Chopped } \\
\text { hay }\end{array}$ & $\begin{array}{l}\text { Supplement } \\
\text { pellet }\end{array}$ & $\begin{array}{l}0 \% \text { hay } \\
0 \% \mathrm{CSH}\end{array}$ & $\begin{array}{l}0 \% \text { hay } \\
5 \% \mathrm{CSH}\end{array}$ & $\begin{array}{l}15 \% \text { hay } \\
0 \% \text { CSH }\end{array}$ \\
\hline 25,000 & 0.0 & 4.4 & 0.0 & 0.0 & 0.0 & 0.8 \\
\hline 16,000 & 0.0 & 4.7 & 0.0 & 0.0 & 0.0 & 0.8 \\
\hline 8,000 & 0.0 & 8.4 & 0.0 & 0.0 & 0.0 & 1.4 \\
\hline 3,350 & 0.0 & 24.9 & 0.4 & 34.1 & 31.8 & 32.8 \\
\hline 2,360 & 55.8 & 6.5 & 4.1 & 20.2 & 19.3 & 18.1 \\
\hline 1,700 & 20.9 & 11.3 & 9.4 & 16.9 & 19.0 & 16.1 \\
\hline 1,180 & 10.1 & 12.6 & 17.6 & 8.8 & 9.1 & 9.4 \\
\hline 850 & 6.0 & 10.8 & 21.5 & 6.9 & 7.3 & 7.0 \\
\hline 600 & 3.4 & 8.7 & 16.4 & 6.1 & 6.0 & 6.5 \\
\hline 425 & 1.7 & 3.0 & 9.9 & 1.9 & 2.2 & 2.1 \\
\hline 300 & 0.8 & 1.7 & 8.5 & 1.3 & 1.6 & 1.4 \\
\hline 212 & 0.6 & 1.3 & 7.0 & 1.5 & 1.4 & 1.5 \\
\hline 150 & 0.3 & 0.9 & 3.0 & 1.2 & 1.2 & 1.2 \\
\hline 106 & 0.4 & 0.8 & 2.2 & 1.1 & 1.1 & 1.1 \\
\hline 75 & $<0.05$ & $<0.05$ & $<0.05$ & $<0.05$ & $<0.05$ & $<0.05$ \\
\hline Pan & $<0.05$ & $<0.05$ & $<0.05$ & $<0.05$ & $<0.05$ & $<0.05$ \\
\hline$>1,180^{1}$ & 86.8 & 72.8 & 31.5 & 80.0 & 79.2 & 79.4 \\
\hline Mean $^{1,2}$ & 2,022 & 2,174 & 795 & 2,050 & 1,991 & 2,087 \\
\hline
\end{tabular}

\footnotetext{
${ }^{1}$ Warner (1991) and Porter et al. (2007) suggested that approximately $80 \%$ or more of the particles in a complete starter should be greater than $1,190 \mu \mathrm{m}$ and have a weighted mean particle size of approximately $2,000 \mu \mathrm{m}$ or greater.

${ }^{2}$ Geometric mean particle size $(\mu \mathrm{m})$.
}

ADG and EBWADG. The difference in calf ADG between the 0 and $10 \% \mathrm{CSH}$ treatments was $12 \%$ from 0 to $56 \mathrm{~d}$ and $9 \%$ from 56 to $84 \mathrm{~d}$. Starter intake $(\mathrm{kg} / \mathrm{d})$ tended $(P<0.15)$ to decline linearly to $\mathrm{CSH}$ percentage in the starter from 1 to $28 \mathrm{~d}$ and starter intake declined linearly $(P<0.05)$ to $\mathrm{CSH}$ percentage in the starter from 28 to $56 \mathrm{~d}, 1$ to $56 \mathrm{~d}$, and 56 to $84 \mathrm{~d}$. However, starter intake as a percentage of BW did not change $(P$ $<0.15)$ with treatment. Starter intake as a percentage of BW from 56 to $84 \mathrm{~d}$ tended $(P<0.07)$ to be less for calves fed $5 \%$ hay vs. $5 \% \mathrm{CSH}$. Intake of NDF increased $(P<0.01)$ from 28 to $56 \mathrm{~d}$ and 56 to $84 \mathrm{~d}$ as CSH increased in the diet. Efficiency was numerically improved $(P=0.16)$ from 0 to $28 \mathrm{~d}$ in calves fed the starters with 5\% CSH and 5\% hay compared with calves fed the starter with no roughage. Efficiency from 0 to $56 \mathrm{~d}$ declined $(P<0.04)$ as CSH increased in the diet. Efficiency from 28 to $56 \mathrm{~d}$ and 56 to $84 \mathrm{~d}$ was not different $(P>0.15)$ among calves fed $5 \% \mathrm{CSH}$ or $5 \%$ hay than calves fed $0 \%$ roughage. No other measurements differed $(P>0.15)$.

In study 3, ADG, EBWADG, starter intake, efficiency, and hip width change declined linearly $(P<0.05)$ as hay percentage increased in the starter from 28 to 56 $\mathrm{d}$ and 0 to $56 \mathrm{~d}$ (Table 5). The change in ADG from 0 to $56 \mathrm{~d}$ between calves fed the 0 and $5 \%$ hay treatments was $16 \%$. No other measurements differed $(P>0.15)$.
In study 4, ADG, EBWADG, starter intake, and NDF intake were less $(P<0.05)$ for calves fed starters with 15 vs. $5 \%$ hay (Table 6 ). The change in calf ADG between treatments from 56 to $84 \mathrm{~d}$ was $12 \%$. No other measurements differed $(P>0.15)$.

\section{DISCUSSION}

Both Warner et al. (1956) and Stobo et al. (1966) report that even though rumen capacity and tissue mass increase as forage percentage increases in the diet of the young calf, empty BW gain decreases. In these studies, as concentrates replaced forage in starters (equal in $\mathrm{CP},>17 \% \mathrm{CP}$ as-fed), the development of the rumen epithelium (papillae) and EBWADG increased. Our results in studies 1,2 , and 3 substantiate these results. As dietary hay or CSH increased, ADG and EBWADG decreased in calves less than 8 wk old.

Jahn et al. (1970) and Jahn and Chandler (1975) fed Holstein bull calves between 8 and 20 or 22 wk of age diets with different amounts ADF using straw, corn cobs, or grass hay as sources of ADF. Both reported that EBWADG declined as ADF increased. Jahn et al. (1970) reported that starter intake responded quadratically to straw concentration in the diet, increasing to plateau at $32.5 \%$ straw and decreasing thereafter. The intake of starter (as-fed) as a percentage of BW in the current 4 studies ranged from 2.8 to $3.0 \%$ of BW from 
Table 3. Effect of concentration of cottonseed hulls (CSH) in the starters fed in study 1

\begin{tabular}{|c|c|c|c|c|}
\hline Item & $0 \% \mathrm{CSH}^{1}$ & $5 \% \mathrm{CSH}^{1}$ & SEM & $P$-value \\
\hline Calves, $\mathrm{n}^{2}$ & 24 & 24 & - & - \\
\hline Initial serum protein, $\mathrm{mg} / \mathrm{dL}$ & 5.3 & 5.3 & 0.3 & 0.63 \\
\hline Initial weight, $\mathrm{kg}$ & 39.5 & 39.7 & 0.6 & 0.77 \\
\hline \multicolumn{5}{|l|}{$\mathrm{ADG}, \mathrm{kg}$} \\
\hline 1-28 d (preweaning) & 0.250 & 0.275 & 0.023 & 0.44 \\
\hline $28-56 \mathrm{~d}$ & 0.592 & 0.558 & 0.035 & 0.10 \\
\hline $1-56 \mathrm{~d}$ & 0.421 & 0.417 & 0.028 & 0.57 \\
\hline $56-84 \mathrm{~d}$ & 0.885 & 0.858 & 0.043 & 0.11 \\
\hline \multicolumn{5}{|l|}{ EBWADG,${ }^{3} \mathrm{~kg}$} \\
\hline 1-28 d (preweaning) & 0.236 & 0.240 & 0.021 & 0.84 \\
\hline $28-56 \mathrm{~d}$ & 0.559 & 0.521 & 0.031 & 0.07 \\
\hline $1-56 \mathrm{~d}$ & 0.398 & 0.381 & 0.026 & 0.21 \\
\hline $56-84 \mathrm{~d}$ & 0.795 & 0.738 & 0.037 & 0.08 \\
\hline Milk replacer intake, $\mathrm{kg} / \mathrm{d}$ & 0.430 & 0.430 & - & - \\
\hline \multicolumn{5}{|l|}{ Starter intake, $\mathrm{kg} / \mathrm{d}$} \\
\hline 1-28 d (preweaning) & 0.167 & 0.178 & 0.020 & 0.70 \\
\hline $28-56 \mathrm{~d}$ & 1.534 & 1.646 & 0.060 & 0.04 \\
\hline $1-56 \mathrm{~d}$ & 0.850 & 0.912 & 0.057 & 0.42 \\
\hline $56-84 \mathrm{~d}$ & 2.630 & 2.554 & 0.070 & 0.12 \\
\hline \multicolumn{5}{|l|}{ Starter intake, \% of BW } \\
\hline $28-56 \mathrm{~d}$ & 2.80 & 2.98 & 0.09 & 0.05 \\
\hline $56-84 \mathrm{~d}$ & 3.49 & 3.40 & 0.08 & 0.12 \\
\hline \multicolumn{5}{|l|}{ NDF intake, $\mathrm{kg} / \mathrm{d}$} \\
\hline $28-56 \mathrm{~d}$ & 0.218 & 0.280 & 0.009 & 0.03 \\
\hline $56-84 \mathrm{~d}$ & 0.429 & 0.544 & 0.013 & 0.01 \\
\hline \multicolumn{5}{|l|}{ NDF intake, $\%$ of BW } \\
\hline $28-56 \mathrm{~d}$ & 0.40 & 0.51 & 0.02 & 0.02 \\
\hline $56-84 \mathrm{~d}$ & 0.57 & 0.72 & 0.02 & 0.01 \\
\hline \multicolumn{5}{|l|}{ Feed efficiency ${ }^{4}$} \\
\hline 1-28 d (preweaning) & 0.419 & 0.453 & 0.032 & 0.36 \\
\hline $28-56 \mathrm{~d}$ & 0.386 & 0.339 & 0.023 & 0.04 \\
\hline $1-56 \mathrm{~d}$ & 0.396 & 0.370 & 0.031 & 0.28 \\
\hline $56-84 \mathrm{~d}$ & 0.337 & 0.336 & 0.015 & 0.85 \\
\hline \multicolumn{5}{|l|}{ Hip width change, $\mathrm{cm}$} \\
\hline 1-28 d (preweaning) & 1.2 & 1.0 & 0.2 & 0.49 \\
\hline $28-56 \mathrm{~d}$ & 2.4 & 2.4 & 0.2 & 0.96 \\
\hline $1-56 \mathrm{~d}$ & 3.6 & 3.4 & 0.2 & 0.26 \\
\hline $56-84 \mathrm{~d}$ & 2.7 & 2.5 & 0.09 & 0.02 \\
\hline
\end{tabular}

\footnotetext{
${ }^{1}$ During d 1 to 56 , no hay was fed. During d 56 to 84, both treatments contained $5 \%$ hay.

${ }^{2}$ Calves were in individual pens until d 56 and grouped into 6 calves per pen while being maintained on similar diets with or without CSH from d 56 to 84 . Pen was the experimental unit.

${ }^{3}$ Empty BW ADG calculated by adjusting for gut fill as described by Jahn et al. (1976).

${ }^{4}$ Gain divided by milk replacer plus starter intake.
}

28 to $56 \mathrm{~d}$ and 3.2 to $3.7 \%$ of BW from 56 to $84 \mathrm{~d}$. The intake of $\mathrm{NDF}$ as a percentage of $\mathrm{BW}$ ranged from 0.4 to $0.6 \%$ of $\mathrm{BW}$ from 28 to $56 \mathrm{~d}$ and 0.5 to $0.7 \%$ of $\mathrm{BW}$ from 56 to $84 \mathrm{~d}$. Reductions in starter intake occurred in studies 3 and 4 when the concentration of hay was tested as the roughage. Reductions in starter intake in study 2, when CSH levels were tested, are questionable. There was no reduction in starter intake in study 1 when CSH levels were tested. Across these 4 studies, it is difficult to say that there was a maximum intake threshold or limit related to fiber. The fiber content of the diets fed in the current studies would be at the low end of the range of the fiber concentrations fed by Jahn et al. (1970) and Jahn and Chandler (1975), in which intake increased before decreasing. In study 3, intake of $\mathrm{NDF}$ was $0.45 \%$ of $\mathrm{BW}$ from 28 to $56 \mathrm{~d}$, apparently lower than NDF intakes in the other 3 studies, yet intake of starter declined linearly as hay increased. Seventeen percent of the particles in the chopped hay were greater than $8,000 \mu \mathrm{m}$ and the $\mathrm{CSH}$ (or no other ingredient) contained no particles over $8,000 \mu \mathrm{m}$. Possibly, the large particle fraction of the chopped hay was more related to intake limitations than that of NDF or another chemical fiber fraction.

Jahn et al. (1976) also reported carcass gain of energy and protein, and efficiency of gain in 8- to 20-wk-old calves to be inversely related to the $\mathrm{ADF}$ concentration of the diet. As dietary hay or CSH increased, EBWADG 
HILL ET AL.

Table 4. Effect of concentration of cottonseed hulls (CSH) or chopped hay in the starters fed in study 2

\begin{tabular}{|c|c|c|c|c|c|c|c|c|}
\hline \multirow[b]{2}{*}{ Item } & \multirow[b]{2}{*}{$\begin{array}{c}0 \% \\
\mathrm{CSH}\end{array}$} & \multirow[b]{2}{*}{$\begin{array}{c}5 \% \\
\mathrm{CSH}\end{array}$} & \multirow[b]{2}{*}{$\begin{array}{l}10 \% \\
\mathrm{CSH}\end{array}$} & \multirow[b]{2}{*}{$\begin{array}{l}5 \% \\
\text { Hay }\end{array}$} & \multirow[b]{2}{*}{ SEM } & \multicolumn{3}{|c|}{ Contrast $P$-value } \\
\hline & & & & & & $\begin{array}{c}\text { Linear } \\
0,5 \text {, or } 10 \% \\
\text { CSH }\end{array}$ & $\begin{array}{c}\text { Quadratic } \\
0,5 \text {, or } 10 \% \\
\text { CSH }\end{array}$ & $\begin{array}{c}5 \% \text { CSH } \\
\text { vs. } \\
5 \% \text { hay }\end{array}$ \\
\hline Calves, $\mathrm{n}^{1}$ & 12 & 12 & 12 & 12 & - & - & - & - \\
\hline Initial serum protein, $\mathrm{mg} / \mathrm{dL}$ & 5.0 & 5.2 & 5.0 & 5.2 & 0.2 & - & - & - \\
\hline Initial weight, $\mathrm{kg}$ & 41.7 & 43.5 & 42.5 & 42.5 & 1.7 & - & - & - \\
\hline \multicolumn{9}{|l|}{$\mathrm{ADG}, \mathrm{kg}$} \\
\hline 1-28 d (preweaning) & 0.503 & 0.439 & 0.416 & 0.487 & 0.037 & 0.10 & 0.65 & 0.35 \\
\hline $28-56 \mathrm{~d}$ & 0.790 & 0.767 & 0.719 & 0.721 & 0.032 & 0.03 & 0.83 & 0.51 \\
\hline $1-56 \mathrm{~d}$ & 0.647 & 0.603 & 0.568 & 0.604 & 0.035 & 0.02 & 0.92 & 0.98 \\
\hline $56-84 \mathrm{~d}$ & 1.215 & 1.221 & 1.098 & 1.220 & 0.018 & 0.05 & 0.01 & 0.78 \\
\hline \multicolumn{9}{|l|}{ EBWADG,$^{2} \mathrm{~kg}$} \\
\hline 1-28 d (preweaning) & 0.471 & 0.380 & 0.331 & 0.434 & 0.033 & 0.04 & 0.69 & 0.21 \\
\hline $28-56 \mathrm{~d}$ & 0.745 & 0.711 & 0.656 & 0.672 & 0.030 & 0.02 & 0.75 & 0.58 \\
\hline $1-56 \mathrm{~d}$ & 0.608 & 0.545 & 0.493 & 0.553 & 0.031 & 0.02 & 0.63 & 0.84 \\
\hline $56-84 \mathrm{~d}$ & 1.146 & 1.132 & 1.002 & 1.137 & 0.015 & 0.06 & 0.02 & 0.61 \\
\hline Milk replacer intake, $\mathrm{kg} / \mathrm{d}$ & 0.645 & 0.645 & 0.645 & 0.645 & - & - & - & - \\
\hline \multicolumn{9}{|l|}{ Starter intake, kg/d } \\
\hline 1-28 d (preweaning) & 0.266 & 0.225 & 0.191 & 0.284 & 0.038 & 0.07 & 0.94 & 0.29 \\
\hline $28-56 \mathrm{~d}$ & 2.085 & 1.972 & 1.960 & 1.882 & 0.045 & 0.05 & 0.74 & 0.61 \\
\hline $1-56 \mathrm{~d}$ & 1.175 & 1.098 & 1.075 & 1.083 & 0.049 & 0.04 & 0.78 & 0.89 \\
\hline $56-84 \mathrm{~d}$ & 3.515 & 3.404 & 3.239 & 3.214 & 0.100 & 0.04 & 0.44 & 0.13 \\
\hline \multicolumn{9}{|l|}{ Starter intake, \% of BW } \\
\hline $28-56 \mathrm{~d}$ & 3.12 & 2.96 & 3.05 & 2.84 & 0.08 & 0.23 & 0.51 & 0.47 \\
\hline $56-84 \mathrm{~d}$ & 3.70 & 3.61 & 3.61 & 3.44 & 0.12 & 0.12 & 0.69 & 0.07 \\
\hline \multicolumn{9}{|l|}{ NDF intake, $\mathrm{kg} / \mathrm{d}$} \\
\hline $28-56 \mathrm{~d}$ & 0.294 & 0.345 & 0.410 & 0.307 & 0.008 & 0.01 & 0.71 & 0.63 \\
\hline $56-84 \mathrm{~d}$ & 0.496 & 0.596 & 0.677 & 0.524 & 0.011 & 0.01 & 0.90 & 0.20 \\
\hline \multicolumn{9}{|l|}{ NDF intake, $\%$ of BW } \\
\hline $28-56 \mathrm{~d}$ & 0.44 & 0.52 & 0.64 & 0.46 & 0.02 & 0.01 & 0.68 & 0.29 \\
\hline $56-84 \mathrm{~d}$ & 0.52 & 0.63 & 0.76 & 0.56 & 0.02 & 0.01 & 0.85 & 0.09 \\
\hline \multicolumn{9}{|l|}{ Feed efficiency ${ }^{3}$} \\
\hline 1-28 d (preweaning) & 0.551 & 0.497 & 0.494 & 0.518 & 0.029 & 0.16 & 0.46 & 0.60 \\
\hline $28-56 \mathrm{~d}$ & 0.382 & 0.392 & 0.370 & 0.382 & 0.013 & 0.53 & 0.31 & 0.58 \\
\hline $1-56 \mathrm{~d}$ & 0.433 & 0.425 & 0.407 & 0.427 & 0.010 & 0.04 & 0.73 & 0.86 \\
\hline $56-84 \mathrm{~d}$ & 0.346 & 0.359 & 0.339 & 0.380 & 0.016 & 0.35 & 0.51 & 0.78 \\
\hline \multicolumn{9}{|l|}{ Hip width change, $\mathrm{cm}$} \\
\hline 1-28 d (preweaning) & 1.4 & 1.4 & 1.8 & 1.6 & 0.2 & 0.13 & 0.23 & 0.40 \\
\hline $28-56 \mathrm{~d}$ & 2.7 & 2.8 & 2.1 & 2.3 & 0.4 & 0.24 & 0.51 & 0.31 \\
\hline $1-56 \mathrm{~d}$ & 4.1 & 4.2 & 3.9 & 3.9 & 0.4 & 0.71 & 0.76 & 0.62 \\
\hline $56-84 \mathrm{~d}$ & 3.1 & 3.1 & 3.0 & 3.2 & 0.2 & 0.42 & 0.69 & 0.94 \\
\hline
\end{tabular}

${ }^{1}$ Calves were in individual pens until d 56 and grouped into 6 calves per pen while being maintained on the same dietary treatment from d 56 to 84 . Pen was the experimental unit.

${ }^{2}$ Empty BW ADG calculated by adjusting for gut fill as described by Jahn et al. (1976).

${ }^{3}$ Gain divided by milk replacer plus starter intake.

decreased in calves between 8 and 12 wk old in studies 1,2 , and 4, substantiating the EBWADG results from the 1970s (Jahn et al., 1970, 1976; Jahn and Chander, 1975).

Gut fill increased and the CP requirement of the calf increased as fiber in the diet increased (Jahn et al., 1970, 1976). Jahn et al. (1970) reported that gut fill as a percentage of BW ranged from approximately 10.5 to $24 \%$ of BW and increased linearly as straw increased from 5 to $60 \%$ (5.0 to $34.7 \% \mathrm{ADF}$; all on a $90 \% \mathrm{DM}$ basis). Jahn et al. (1976) reported gut fill to range from approximately 8.5 to $16 \%$ of $\mathrm{BW}$ and to increase linearly as dietary $\mathrm{ADF}$ concentration (from corn cobs and grass hay) increased from 11 to $25 \%$ and as CP concentration decreased from 17.5 to $9 \% \mathrm{CP}$ (all on a $90 \% \mathrm{DM}$ basis). An interaction of $\mathrm{ADF}$ and $\mathrm{CP}$ concentration of the diet influenced EBWADG and intake. Jahn et al. (1976) reported that the $\mathrm{CP}$ requirement ( $\mathrm{g} / \mathrm{d}$ and \% of diet) and projected intake for $0.6 \mathrm{~kg}$ of EBWADG increased as $\mathrm{ADF}$ concentration of the diet increased. This relationship was similar at $0.8 \mathrm{~kg}$ of EBWADG; however, calves in Jahn et al. (1976) did not consume enough of the $25 \% \mathrm{ADF}$ starter to achieve this gain. The increase in $\mathrm{CP}$ requirement with increasing fiber was suggested 
Table 5. Effect of concentration of chopped hay in the starters fed in study 3

\begin{tabular}{|c|c|c|c|c|c|c|}
\hline \multirow[b]{2}{*}{ Item } & \multirow[b]{2}{*}{ 0\% Hay } & \multirow[b]{2}{*}{$2.5 \%$ Hay } & \multirow[b]{2}{*}{$5 \%$ Hay } & \multirow[b]{2}{*}{ SEM } & \multicolumn{2}{|c|}{ Contrast $P$-value } \\
\hline & & & & & Linear & Quadratic \\
\hline Calves, $\mathrm{n}^{1}$ & 16 & 16 & 16 & - & - & - \\
\hline Initial serum protein, $\mathrm{mg} / \mathrm{dL}$ & 5.1 & 5.3 & 5.0 & 0.11 & 0.58 & 0.10 \\
\hline Initial weight, $\mathrm{kg}$ & 42.8 & 42.4 & 42.1 & 0.9 & 0.57 & 0.99 \\
\hline \multicolumn{7}{|l|}{$\mathrm{ADG}, \mathrm{kg}$} \\
\hline 1-28 d (preweaning) & 0.420 & 0.407 & 0.421 & 0.025 & 0.99 & 0.65 \\
\hline $28-56 \mathrm{~d}$ & 0.858 & 0.790 & 0.645 & 0.031 & 0.01 & 0.32 \\
\hline $1-56 \mathrm{~d}$ & 0.639 & 0.598 & 0.533 & 0.022 & 0.01 & 0.64 \\
\hline \multicolumn{7}{|l|}{ EBWADG,$^{2} \mathrm{~kg}$} \\
\hline 1-28 d (preweaning) & 0.390 & 0.370 & 0.374 & 0.022 & 0.42 & 0.17 \\
\hline $28-56 \mathrm{~d}$ & 0.808 & 0.741 & 0.601 & 0.027 & 0.01 & 0.23 \\
\hline $1-56 \mathrm{~d}$ & 0.599 & 0.555 & 0.487 & 0.025 & 0.01 & 0.39 \\
\hline Milk replacer intake, kg/d & 0.645 & 0.645 & 0.645 & - & - & - \\
\hline \multicolumn{7}{|l|}{ Starter intake, kg/d } \\
\hline 1-28 d (preweaning) & 0.17 & 0.15 & 0.16 & 0.017 & 0.68 & 0.67 \\
\hline $28-56 \mathrm{~d}$ & 2.04 & 1.90 & 1.70 & 0.070 & 0.01 & 0.73 \\
\hline $1-56 \mathrm{~d}$ & 1.11 & 1.03 & 0.93 & 0.041 & 0.01 & 0.84 \\
\hline \multicolumn{7}{|l|}{ Starter intake, \% of BW } \\
\hline $28-56 \mathrm{~d}$ & 3.06 & 2.93 & 2.70 & 0.12 & 0.01 & 0.89 \\
\hline \multicolumn{7}{|l|}{ NDF intake, $\mathrm{kg} / \mathrm{d}$} \\
\hline $28-56 \mathrm{~d}$ & 0.298 & 0.291 & 0.278 & 0.011 & 0.92 & 0.95 \\
\hline \multicolumn{7}{|l|}{ NDF intake, $\%$ of $\mathrm{BW}$} \\
\hline $28-56 \mathrm{~d}$ & 0.45 & 0.45 & 0.44 & 0.02 & 0.74 & 0.82 \\
\hline \multicolumn{7}{|l|}{ Feed efficiency ${ }^{3}$} \\
\hline 1-28 d (preweaning) & 0.515 & 0.506 & 0.524 & 0.025 & 0.79 & 0.66 \\
\hline $28-56 \mathrm{~d}$ & 0.421 & 0.418 & 0.379 & 0.010 & 0.01 & 0.16 \\
\hline $1-56 \mathrm{~d}$ & 0.447 & 0.443 & 0.426 & 0.007 & 0.05 & 0.48 \\
\hline \multicolumn{7}{|l|}{ Hip width change, $\mathrm{cm}$} \\
\hline 1-28 d (preweaning) & 1.8 & 1.8 & 1.7 & 0.14 & 0.75 & 0.78 \\
\hline $28-56 \mathrm{~d}$ & 3.0 & 2.8 & 2.6 & 0.13 & 0.01 & 0.88 \\
\hline $1-56 \mathrm{~d}$ & 4.8 & 4.6 & 4.3 & 0.20 & 0.04 & 0.92 \\
\hline
\end{tabular}

${ }^{1}$ Calves were in individual pens. Pen was the experimental unit.

${ }^{2}$ Empty BW ADG calculated by adjusting for gut fill as described by Jahn et al. (1976).

${ }^{3}$ Gain divided by milk replacer plus starter intake.

to be a function of increased metabolic fecal nitrogen, lower CP digestibility of the roughage, and increased need for RDP in high-fiber diets.

When comparing diets with different fiber concentrations, correction for gut fill is needed. A change of $1 \%$ of $\mathrm{BW}$ as fill in a $60-\mathrm{kg}$ calf gaining $0.7 \mathrm{~kg}$ ADG over $28 \mathrm{~d}$ would change ADG by approximately $3 \%$. A $1 \%$ change in fill as a percentage of BW equates to a $2.4 \%$ change in diet $\mathrm{ADF}$ concentration based on the coefficient of 0.41 diet $\mathrm{ADF}$ percentage in the equation of Jahn et al. (1976). Additionally, feeding inadequate CP diets will increase gut fill based on the coefficient of negative 0.39 diet CP percentage in the equation of Jahn et al. (1976). These gut fill and adequacy of CP data from Jahn et al. $(1970,1976)$ are important to consider when evaluating data from Kincaid (1980) and Coverdale et al. (2004).

At least 2 research groups (Kincaid, 1980; Coverdale et al., 2004) have reported increased ADG when feeding high-fiber starters in contrast to the current studies.
Kincaid (1980) fed pelleted starters ranging from 13.0 to $14.6 \% \mathrm{CP}$ as-fed and reported increased postweaning ADG (+28 to $32 \%)$ and total intake ( +18 to $26 \%)$. Calves in that study were fed $20 \%$ alfalfa pellets blended with the starter or free-choice long alfalfa hay with the starter. However, their starters were possibly deficient in CP (NRC, 2001; Hill et al., 2007a) and the additional $\mathrm{N}$ from alfalfa may have confounded the effects of fiber. Additionally, the very large (28 to $30 \%$ ) change in ADG with a smaller (18 to $26 \%$ ) change in starter intake appears to suggest a gut fill effect, rather than a tissue gain effect.

Coverdale et al. (2004) conducted 2 studies to evaluate the effect of dietary forage concentration and form on calf performance. These researchers added 7.5 or $15 \%$ chopped hay to a textured diet (all $20+\%$ CP asfed). Their hay was described as "approximately 8 to 19 $\mathrm{mm}$ " in length using the Penn State Forage Separator (Lammers et al., 1996), and appeared to be larger than the hay we fed. Other particle size descriptions for their 
Table 6. Effect of concentration of chopped hay in the starters fed in study 4

\begin{tabular}{lcccc}
\hline Item & $5 \%$ hay & 15\% hay & SEM & $P$-value \\
\hline Calves, $\mathrm{n}^{1}$ & 24 & 24 & - & - \\
Initial weight, kg $_{\text {ADG, kg }}$ & 70.2 & 69.8 & 0.5 & 0.56 \\
EBWADG, ${ }^{2} \mathrm{~kg}$ & 1.03 & 0.90 & 0.022 & 0.01 \\
Starter intake, kg/d $_{\text {Starter intake, \% of BW }}$ & 0.93 & 0.79 & 0.020 & 0.01 \\
NDF intake, kg/d & 2.69 & 2.36 & 0.063 & 0.01 \\
NDF intake, \% of BW & 0.44 & 2.86 & 0.079 & 0.01 \\
Feed efficiency & 0.52 & 0.50 & 0.013 & 0.01 \\
Hip width change, cm $^{3}$ & 0.39 & 0.39 & 0.016 & 0.01 \\
\hline
\end{tabular}

${ }^{1}$ Calves grouped into 6 calves per pen. Pen was the experimental unit.

${ }^{2}$ Empty BW ADG calculated by adjusting for gut fill as described by Jahn et al. (1976).

${ }^{3}$ Gain divided by starter intake.

diets were not described. They fed a $20 \% \mathrm{CP}, 20 \%$ fat MR at $10 \%$ of BW. In study 1 by Coverdale et al. (2004), preweaning $\mathrm{ADG}(0.17 \mathrm{~kg} / \mathrm{d})$ was quite low but similar among treatments. These authors reported increased postweaning ADG and feed efficiency in their study 1 when hay was fed. Compared with the control calves $(0.91 \mathrm{~kg} / \mathrm{d})$, postweaning ADG increased $34 \%$ in calves fed $7.5 \%$ hay and $12 \%$ in calves fed $15 \%$ hay, whereas intake tended to be $5 \%$ greater in calves fed 7.5 vs. $0 \%$ hay. This very large (34\%) change in ADG with minimal change in starter intake appears to suggest a gut fill effect, rather than a tissue gain effect. In their study 1 , Coverdale et al. (2004) restricted starter intake to be constant across treatments until weaning at $52 \mathrm{~d}$ on test and used calves purchased from sale barns. In their study 2 , they used single-source calves from different breeds and did not restrict intake or report weaning age. In their study 2 , starter intake was greater in calves fed 7.5 and $15 \%$ chopped hay; however, ADG did not differ with treatment, contrary to their study 1 . In study 2 of Coverdale et al. (2004), a single source of calves fed hay could have had a greater gut fill than calves fed no hay resulting in a reduced EBWADG for calves fed hay vs. no hay. They bedded with wood shavings in study 1 and either shavings or straw in study 2 . No studies are apparent to postulate differences in consumption of straw and shavings; however, calves could have consumed bedding types preferentially, confounding the results. Straw bedding has been reported to support more ADG in calves during cold weather than shavings, presumably because of its greater insulating value (Hill et al., 2007b).

The improvements in ADG from feeding hay with starters to calves in the study of Kincaid (1980) and in study 1 of Coverdale et al. (2004) could have actually been a gut fill effect rather than a tissue gain effect.
Their surprisingly large improvements in ADG (approximately $30 \%$ ) are hard to imagine as tissue gain because there was not a corresponding increase in intake to support the BW gain. If there was a gut fill effect in the studies of Kincaid (1980) and Coverdale et al. (2004), that would explain the differences in their results of fiber not reducing ADG as was observed in the current 4 trials.

\section{CONCLUSIONS}

In each of the 4 studies, a textured starter with adequate particle size (Porter et al., 2007) was fed to calves managed in pens with straw bedding. The results were consistent and yielded the same interpretation whether using ADG or EBWADG. In studies 1, 2, and 3, fiber in the form of 5 to $10 \% \mathrm{CSH}$ or 2.5 to $5 \%$ hay depressed starter intake, ADG, and efficiency in calves 30 to 60 d old. In calves 60 to $88 \mathrm{~d}$ old, feeding $5 \% \mathrm{CSH}$ with $5 \%$ hay (study 1), $10 \% \mathrm{CSH}$ (study 2), and $15 \%$ hay (study 4) tended to reduce or reduced starter intake and ADG compared with 5\% hay, 5\% CSH, or no roughage. Roughage diluting the energy density and digestibility of the diet explains part of the reduction in ADG (Warner et al., 1956). The reduction in starter intake with addition of chopped hay with some large particles could be a function of limited rumen capacity in the neonate; however, the rumen has been shown to readily increase in volume when hay is fed (Warner et al., 1956). Calves between 60 and $88 \mathrm{~d}$ that were fed starters with $5 \%$ roughage appeared more efficient than calves fed starters with 0 or $10 \%$ roughage (study 2 ). Adding $5 \%$ roughage from 60 to $88 \mathrm{~d}$ could be beneficial to improve efficiency because of the ability of the forage to maintain a higher rumen $\mathrm{pH}$ and increase salivary flow (Hibbs et al., 1956). Adding low-energy roughage to starters with adequate coarseness reduced postweaning (30 to $60 \mathrm{~d}$ of age) ADG in calves bedded on straw. Limited (5\%) amounts of roughage may have improved efficiency in calves between 60 and $88 \mathrm{~d}$ of age. However, 10 to $15 \%$ roughage in the diet of calves between 60 and $88 \mathrm{~d}$ of age reduced ADG and efficiency. Roughage at concentrations from 2.5 to $15 \%$ of the diet changed starter intake in an inconsistent manner across the 4 trials.

\section{REFERENCES}

AOAC. 1996. Official Methods of Analysis. Vol. I 16th ed. Association of Official Analytical Chemists, Arlington, VA.

ASAE. 1983. Method of determining and expressing fineness of feed materials by sieving. Page 325 in ASAE Standard S319, Agriculture Engineers Yearbook of Standards, St. Joseph, MI.

Brownlee, A. 1956. The development of rumen papillae in cattle fed on different diets. Br. Vet. J. 112:369-375. 
Coverdale, J. A., H. D. Tyler, J. D. Quigley III, and J. A. Brumm. 2004. Effect of various levels of forage and form of diet on rumen development and growth in calves. J. Dairy Sci. 87:2554-2562.

FASS. 1999. Guide for the Care and Use of Agricultural Animals in Agricultural Research and Teaching. 1st rev. ed. Federation of Animal Science Societies, Savoy, IL.

Flatt, W. P., R. G. Warner, and J. K. Loosli. 1958. Influence of purified materials on the development of the ruminant stomach. J. Dairy Sci. 41:1593-1600.

Greenwood, R. H., J. L. Morril, E. C. Titgemeyer, and G. A. Kennedy. 1997. A new method of measuring diet abrasion and its effect on the development of the forestomach. J. Dairy Sci. 80:2534-2541.

Heinrichs, A. J., S. J. Wells, H. S. Hurd, G. W. Hill, and D. A. Dargatz. 1994. The national dairy heifer evaluation project: A profile of heifer management practices in the United States. J. Dairy Sci. $77: 1548-1555$.

Hibbs, J. W., H. R. Conrad, W. D. Pounden, and N. Frank. 1956. A high roughage system for raising calves based on early development of rumen function. VI. Influence of hay to grain ratio on calf performance, rumen development, and certain blood changes. J. Dairy Sci. 39:171-179.

Hill, T. M., J. M. Aldrich, R. L. Schlotterbeck, and H. G. Bateman II. 2007a. Protein concentration for starters fed to transported neonatal calves. Prof. Anim. Sci. 23:123-134.

Hill, T. M., H. G. Bateman II, J. M. Aldrich, and R. L. Schlotterbeck. 2007b. Effects of feeding rate of milk replacers and bedding material for calves in a cold naturally ventilated nursery. Prof. Anim. Sci. 23:656-664.

Jahn, E., and P. T. Chandler. 1975. Performance and nutrient requirements of calves fed varying percentages of protein and fiber. J. Anim. Sci. 41:724-735.

Jahn, E., P. T. Chandler, and R. F. Kelly. 1976. Nutrient accumulation and prediction of body composition of 20 -week old calves fed varying percentages of protein and fiber. J. Anim. Sci. 42:737-744.

Jahn, E., P. T. Chandler, and C. E. Polan. 1970. Effects of fiber and ratio of starch to sugar on performance of ruminating calves. J. Dairy Sci. 53:466-474.

Kincaid, R. L. 1980. Alternative methods of feeding alfalfa to calves. J. Dairy Sci. 63:91-94.
Lammers, B. P., D. R. Buckmaster, and A. J. Heinrichs. 1996. A simple method for the analysis of particle sizes of forage and total mixed rations. J. Dairy Sci. 79:922-928.

McGavin, M. D., and J. L. Morrill. 1976. Scanning electron microscopy of ruminal papillae if fed various amounts and forms of roughage. Am. J. Vet. Res. 37:497-508.

National Research Council. 2001. Nutrient Requirements of Dairy Cattle. 7th rev. ed. Natl. Acad. Sci., Washington, DC.

Porter, J. C., R. G. Warner, and A. F. Kertz. 2007. Effect of fiber level and physical form of starter on growth and development of dairy calves fed no forage. Prof. Anim. Sci. 23:395-400.

Robertson, J. B., and P. J. Van Soest. 1981. The Detergent System of Analysis and its Application to Human Foods. Cornell University, Ithaca, NY.

Sander, E. G., R. G. Warner, H. N. Harrison, and J. K. Loosli. 1959 The stimulatory effect of sodium butyrate and sodium propionate on the development of rumen mucosa in the young calf. J. Dairy Sci. 42:1600-1605.

Shaver, R. D., A. J. Nytes, L. D. Satter, and N. A. Jorgensen. 1988. Influence of feed intake, forage physical form, and forage fiber content on particle size of masticated forage, ruminal digesta, and feces of dairy cattle. J. Dairy Sci. 71:1566-1572.

Stobo, I. J. F., J. H. B. Roy, and H. J. Gaston. 1966. Rumen development in the calf. 1 . The effect of diets containing different proportions of concentrates to hay on rumen development. Br. J. Nutr. 20:171-188.

Tamate, H., A. D. McGilliard, N. L. Jacobson, and R. Getty. 1962. Effect of various dietaries on anatomical development of the stomach in the calf. J. Dairy Sci. 45:408-420.

Van Soest, P. J., J. B. Robertson, and B. A. Lewis. 1991. Methods for dietary fiber, neutral detergent fiber, non-starch polysaccharides in relation to animal nutrition. J. Dairy Sci. 74:3583-3597.

Warner, R. G. 1991. Nutritional factors affecting the development of a functional ruminant-A historical perspective. Pages 1-12 in Proc. Cornell Nutr. Conf., Cornell, University, Ithaca, NY.

Warner, R. G., W. P. Flatt, and J. K. Loosli. 1956. Dietary factors influencing the development of the animal's stomach. J. Agric. Food Chem. 4:788-792. 